\title{
DIRASAH
}

Volume 2, Number 1, Februari 2019

p-ISSN: 2615-0212 | e-ISSN: 2621-2838

https://ejournal.iaifa.ac.id/index.php/dirasah

\begin{tabular}{|c|c|c|}
\hline Accepted: & Revised: & Published: \\
November 2018 & Desember 2019 & Februari 2019 \\
\hline
\end{tabular}

\section{Penerapan Manajemen Kesiswaan di Madrasah Diniyah Haji Ya'qub Lirboyo Kota Kediri}

\author{
Wildan Habibi \\ Institut Agama Islam Faqih Asy'ari Kediri, Indonesia \\ e-mail:wildanhbb99@gmail.com
}

\begin{abstract}
Madrasah as part of educational institution that appear in Indonesia, that madrasah has been long participated in improving human resources and educating life of the Indonesian people. The other hand madrasah is madrasah diniyah. As part of Islamic educational institutions, madrasas diniyah also manages several things that related to the educational components such as the management of student or learner. This research used the descriptive-qualitative of paradigm approach. The results of the research showed that The first Diniyyah Madrasah Haji Ya'qub has been able to implement some things that become part of the student management in according to existing regulations. The second there are problems faced both diniyyah Madrasah Haji Ya'qub, in implementing student management such as a) There are many students who have not been able to recognize to the social environment in the location of madrasah. b) The students' interest to understand the lessons is low. c) The students' attendance rate is less than the maximum. The third to face those problems madrasah diniyah haji ya'qub has some efforts as follows: a) Urge to all teachers to instruct their students to participate to the events to know the students' physical and social environment. $b$ ) Instructed to the teachers to pay attention to their students to be active in all of activities of madrasah c) The functionaries give the warning and punishment to the students who are not going to School or discussion.
\end{abstract}

\section{Keywords: Student Management, Madrasah Diniyah}




\section{Penerapan Manajemen Kesiswaan di Madrasah Diniyah Haji Ya'qub Lirboyo Kota Kediri}

\section{Pendahuluan}

Dewasa ini, setidaknya dikenal tiga lembaga pendidikan yang cukup eksis di Indonesia yaitu sekolah, madrasah dan pesantren. Padahal sebelum diadakan pembaruan sistem pendidikan, baik yang diperkenalkan oleh kolonial Belanda maupun kaum modernis, dikenal beberapa lembaga pendidikan tradisional Islam di berbagai daerah di Nusantara ini seperti pesantren di pulau Jawa, surau di Minangkabau, dan dayah di Aceh. ${ }^{1}$ Madrasah sebagai bagian dari lembaga pendidikan yang muncul di Indonesia telah lama berpartisipasi dalam meningkatkan sumber daya manusia dan mencerdaskan kehidupan bangsa. Dalam cakupan istilah madrasah dikenal pula istilah madrasah diniyah. Secara umum, setidaknya sudah ada beberapa karakteristik pendidikan diniyah di bumi nusantara ini. Pertama, Pendidikan Diniyah Takmiliyah yang berada di tengah masyarakat dan tidak berada dalam lingkaran pengaruh pondok pesantren. Pendidikan diniyah jenis ini betul-betul merupakan kreasi dan swadaya masyarakat, yang diperuntukkan bagi anak-anak yang menginginkan pengetahuan agama di luar jalur sekolah formal. Kedua, pendidikan diniyah yang berada dalam lingkaran pondok pesantren tertentu, dan bahkan menjadi urat nadi kegiatan pondok pesantren. Ketiga, pendidikan keagamaan yang diselenggarakan sebagai pelengkap (komplemen) pada pendidikan formal di pagi hari. Keempat, pendidikan diniyah yang diselenggarakan di luar pondok pesantren tapi diselenggarakan secara formal di pagi hari, sebagaimana layaknya sekolah formal.

Sebagai bagian dari sebuah lembaga pendidikan, Madrasah Diniyah Haji Ya'qub yang berada di lingkup Pondok Pesantren Haji Ya'qub berusaha semaksimal mungkin untuk mampu membenahi berbagai komponen-komponen pendidikan yang terdapat di dalamnya, termasuk manajemen kesiswaannya. Melihat banyaknya kegiatan yang harus ditempuh madrasah dalam rangka menerapkan manejemen kesiswaannya, perlu kiranya segera berbenah agar nantinya mampu memberikan fasilitas yang representatif kepada para siswa. Program seleksi dalam proses penerimaan siswa baru, pembagian kelas bagi siswa, beban materi test, kedisiplinan siswa serta perbedaan asal daerah, adat istiadat dan bahasa kiranya perlu mendapatkan perhatian dari pihak madrasah untuk lebih dioptimalkan sebagai salah satu langkah untuk menjadikan Madrasah Diniyah Haji Ya'qub lebih berkembang. Di satu sisi manajer pendidikan Islam

\footnotetext{
${ }^{1}$ Ali Anwar, Pembaruan Pendidikan di Pesantren Lirboyo Kediri (Yogyakarta: Pustaka Pelajar, 2011), 1 .
} 
berbeda dengan manajer pendidikan yang lain. Manajer pendidikan Islam tidak perlu mengikuti manajer lembaga pendidikan lain yang cenderung menekankan input, yaitu dengan hanya menerima siswa atau mahasiswa yang berkualitas baik. Manajer lembaga pendidikan Islam, baik yang berada di lembaga yang baru berkembang maupun yang sudah maju, harus menekankan proses untuk mewujudkan hasil yang maksimal. Oleh karenanya, para siswa yang diterima berasal dari berbagai lapisan intelektual dapat diberdayakan secara maksimal untuk mencapai hasil yang maksimal pada ranah kognitif, afektif, psikomotorik, bahkan metakognitif. ${ }^{2}$ Oleh karena itu perlu kiranya lembaga Madrasah Diniyah Haji Ya'qub meningkatkan hal-hal yang berkaitan dengan para siswa serta proses pembelajaran mengingat siswa-siswa yang terdaftar di madrasah ini sangat beragam mulai perbedaan bahasa, suku serta adat istiadatnya. Dengan beragam perbedaan yang ada tersebut dituntut nantinya untuk meraih tujuan yang sama. Sehingga perlu juga pengenalan lingkungan pondok dan madrasah sebagai bentuk adaptasi terhadap kondisi alam mereka.

Berdasarkan atas permasalahan yang telah diuraikan di atas, maka peneliti merasa tertarik untuk melakukan penelitian dengan judul Penerapan Manajemen Kesiswaan di Madrasah Diniyah Haji Ya'qub Lirboyo Kota Kediri.

\section{Metode Penelitian}

\section{Jenis penelitian}

Metode penelitian merupakan suatu cara yang dilakukan untuk menentukan atau menggali sesuatu yang telah ada untuk kemudian diuji kebenarannya yang mungkin masih diragukan. Oleh karena itu seorang peneliti diharuskan dapat memilih dan menentukan metode yang tepat dan fleksibel guna mencapai tujuannya. Terkait dengan jenis pendekatan penelitian yang ditentukan, penelitian ini menggunakan pendekatan berparadigma deskriptif-kualitatif. Penelitian kualitatif bersifat deskriptif, yaitu data yang terkumpul berbentuk kata - kata, gambar bukan angka - angka. Kalaupun ada angka-angka, sifatnya hanya sebagai penunjang. Data yang diperoleh meliputi transkrip interviu, catatan lapangan, foto, dokumen pribadi dan lain-lain. ${ }^{3}$

\footnotetext{
2 Mujamil Qomar, Manajemen Pendidikan Islam: Strategi Baru Pengelolaan lembaga Pendidikan Islam (Jakarta: Erlangga, 2007), 144.

${ }^{3}$ Sudarwan Danim, Menjadi Peneliti Kualitatif (Bandung: CV Pustaka Setia, 2002), 51.
}

Dirasah, Vol. 2, No. 1, Februari 2019 


\section{Lokasi penelitian}

Penelitian ini dilaksanakan di Madrasah Diniyah Haji Ya'qub Lirboyo Kota Kediri, yang berada di lingkungan pondok pesantren yang berdiri pada tahun 1920 M, yang bernama Pondok Pesantren Haji Ya'qub (PPHY) yang berlokasi di jalan KH. Abdul karim Rt 02 Rw 01 Kelurahan Lirboyo Kecamatan Mojoroto kota Kediri Po. Box. 192 Kota Kediri 64101 Telp. (0354) 772118.

\section{Sumber data}

Adapun sumber data yang digunakan dalam penelitian ini terdiri dari dua macam:

\section{1. data primer}

Data primer yaitu data yang diperoleh langsung dari subjek penelitian dengan menggunakan alat pengukuran atau alat pengambilan data langsung pada subjek sebagai sumber informasi yang dicari. ${ }^{4}$ Dalam data primer tersebut yang menjadi subyek penelitian adalah segenap dewan pengurus dan dewan pengajar Madrasah Diniyah Haji Ya'qub Lirboyo kota Kediri sebagai sumber informasi untuk mendapatkan data-data yang sesuai dengan masalah yang sedang diteliti.

2. data sekunder

Data sekunder adalah yang biasanya telah tersusun dalam bentuk dokumen-dokumen, misalnya data mengenai keadaan geografis suatu daerah, data mengenai produktivitas suatu perguruan tinggi, data mengenai persediaan pangan disuatu daerah dan sebagainya. ${ }^{5}$ Data sekunder dalam penelitian ini adalah bagian tata usaha. Dari data skunder ini diharapkan peneliti memperoleh data-data tertulis berupa profil sekolah, dokumen-dokumen sekolah, jumlah guru, siswa dan fasilitas madrasah.

\section{Prosedur pengumpulan data}

Untuk mendapatkan data yang diperlukan oleh peneliti, maka dalam penelitan ini peneliti menggunakan beberapa metode untuk mengumpulkan data, di antaranya adalah:

1. metode observasi

Dalam hal ini observasi dilakukan ketika peneliti mengamati secara langsung kegiatan belajar mengajar yang sedang berlangsung di Madrasah

\footnotetext{
${ }^{4}$ Marzuki, Metodelogi Riset (Yogyakarta: BPFE-UII, 2000), 57.

${ }^{5}$ Sumadi, Metodologi Penelitian (Jakarta: Raja Grafindo Persada, 1998), 85.
} 
Diniyah haji Ya'qub Lirboyo Kota Kediri. Selain itu observasi ini bertujuan agar dapat memantau, melihat, mengamati dan mencatat hal-hal apa saja yang terjadi. Sehingga dari berbagai proses tersebut dapat dijadikan acuan dalam membuat data secara tertulis.

2. metode wawancara (interview)

Wawancara dimaksudkan untuk memperkuat data observasi yang terjadi di Madrasah Diniyah Haji Ya'qub Lirboyo Kota Kediri dan untuk memperoleh bentuk-bentuk informasi dari semua responden. Wawancara dilakukan terhadap segenap dewan pengurus dan pengajar Madrasah Diniyah Haji Ya'qub, wawancara ini untuk mencari data dan untuk mengetahui tentang penerapan manajemen kesiswaan, kendala-kendala yang di hadapi, dan datadata lainnya yang dianggap perlu, guna untuk melengkapi kelengkapan data pada penelitian ini.

3. metode dokumentasi

Dalam hal ini peneliti mengumpulkan data-data yang diperlukan yang terkait dengan permasalahan, yaitu tentang arsip-arsip yang berkenaan manajemen kesiswaan, selain itu metode ini dipergunakan untuk mengetahui dan mengungkap data latar belakang obyek seperti sejarah berdirinya Madrasah Diniyah Haji Ya'qub, struktur organisasi, sarana prasarana, fasilitas dan lainnya.

\section{Teknis analisis data}

1.reduksi data

Hal ini di tempuh oleh peneliti untuk memilih, memusatkan perhatian, meyederhanakan, mengabstraksikan serta mentransformasikan data yang muncul dari catatan-catatan lapangan. Dengan demikian data yang telah direduksi akan memberikan gambaran yang jelas, dan mempermudah peneliti untuk melakukan pengumpulan data selanjutnya dan mencarinya bila diperlukan.

2. data display (penyajian data)

Setelah data direduksi, maka langkah selanjutnya adalah mendisplaykan data. Melalui penyajian data tersebut, maka data terorganisasikan tersusun dalam pola hubungan, sehingga akan mudah dipahami. Dalam penelitian kualitatif, penyajian data bisa dilakukan dalam bentuk uraian singkat, bagan, hubungan antar kategori, flowchart dan sejenisnya. 


\section{Penerapan Manajemen Kesiswaan di Madrasah Diniyah Haji Ya'qub Lirboyo Kota Kediri}

3.verifikasi (penarikan kesimpulan)

Langkah ketiga dalam analisis data kualitatif adalah penarikan kesimpulan yang dikemukakan dalam penelitian kualitatif harus didukung oleh bukti-bukti yang valid dan konsisten sehingga kesimpulan yang dikemukakan merupakan temuan baru yang bersifat kredibel dan dapat menjawab rumusan masalah yang dirumuskan. ${ }^{6}$

\section{Hasil Penelitian}

Secara rinci, pengelolaan kesiswaan mencakup kegitan-kegiatan dimulai dari perencanaan di bidang kesiswaan, penerimaan siswa baru, pengaturan siswa dalam kelompok-kelompok, pembinaan siswa, berakhir dengan pelepasan siswa dari madrasah, serta kegiatan-kegiatan lain yang berhubungan langsung dengan siswa. ${ }^{7}$ Hasil penelitian di Madrasah Diniyah Haji Ya'qub menyebutkan bahwa:

\section{Perencanaan di bidang Kesiswaan}

Perencanaan memegang peranan penting dalam organisasi karena akan menjadi penentu sekaligus memberi arah terhadap tujuan yang dicapai. Perencanaan adalah adalah proses kegiatan, sedangkan rencana merupakan hasil perencanaan. Perencanaan adalah kegiatan yang berkaitan dengan usaha merumuskan program yang didalamnya memuat segala sesuatu yang akan dilaksanakan, penentuan tujuan, kebijaksanaan, arah yang akan ditempuh, prosedur dan metode yang akan di ikuti dalam usaha pencapain tujuan. ${ }^{8}$

Dalam merencanakan seluruh aktivitas yang menyangkut kegiatan belajar mengajar di Madrasah Diniyah Haji Ya'qub, menurut Bapak M. Shodiqin selaku Mudier MDHY mengatakan bahwasanya setiap akhir tahun, madrasah mengadakan sidang istimewa yang mana anggota sidang ini adalah para masyayih, dewan penasehat madrasah dan dewan harian madrasah. Pada sidang ini membahas tentang rancangan - rancangan yang akan di laksanakan pada agenda tahun ajaran baru atau mendatang, diantaranya adalah rancangan tentang kurikulum, penjadwalan pengajar, pembagian ruang kelas, pembiayaan siswa, tata tertib madrasah dan lainnya. ${ }^{9}$

\footnotetext{
${ }^{6}$ Sugiyono, Memahami Penelitian Kualitatif (Bandung: Alfabeta, 2005), 62.

7 Tim Dosen Jurusan Administrasi Pendidikan FIP IKIP Malang, Administrasi Pendidikan, (Malang: IKIP Malang, 1989), 89.

8 U. Saefullah, Manajemen Pendidikan Islam (Bandung: Pustaka Setia, 2012), 211.

${ }^{9}$ Wawancara dengan M. Shodiqin selaku mudier I MDHY di kantor MDHY pada tanggal 25 Maret 2013.
} 


\section{Penerimaan siswa baru}

Penerimaan peserta didik termasuk salah satu aktivitas dalam manajemen kesiswaan yang sangat penting. Dikatakan demikian, karena aktivitas penerimaan ini menentukan seberapa kualitas input yang dapat diterima oleh sekolah tersebut. ${ }^{10}$ Pengelolaan siswa baru ini harus dilakukan secara terorganisasi dan terencana sehingga kegiatan pembelajaran dapat dilaksanakan pada hari pertama setiap tahun ajara baru. ${ }^{11}$

Pendidikan Islam terdapat model penerimaan santri di pesantren. Lembaga pendidikan Islam tertua ini memiliki keunikan tertentu dalam proses penerimaan santri baru, khususnya pesantren tradisional (salafi). Lembaga pendidikan islam tertua ini memiliki keunikan tertentu dalam proses penerimaan santri baru, khususnya pesantren tradisional (salafi). Penerimaan santri baru di beberapa pesantren tradisional bisa terjadi sewaktu - waktu.

Penerimaan siswa baru Madrasah Diniyah Haji Ya'qub telah membentuk panitia khusus guna menangani para siswa baru yang ingin mendaftar. Kepanitiaan ini telah di bentuk dan di sahkan pada sidang istimewa yang di hadiri oleh para pengasuh dan penasehat madrasah. Bapak Wahib rifa'i selaku panitia ujian masuk mengatakan:

"Di MDHY, panitia ini di namakan PANJIMAS kepanjangan dari Panitia Ujian Masuk, tugasnya adalah mengatur segala keperluan, kebutuhkan, menentukan waktu ujian, sarat-sarat peserta ujian, melayani pendaftaran, membuat materi ujian dan lain sebagainya ". ${ }^{12}$

Penerimaan siswa baru MDHY hanya menggunakan sistem seleksi yaitu dengan mengadakan tes ujian masuk yang berupa ujian tulis dan ujian lesan, disesuaikan tingkat kemampuan siswa seperti yang telah di ungkapkan oleh ustad M. Habibi:

"Digunakannya tes ujian masuk ini untuk menyeleksi para siswa supaya siswa dapat mengikuti pelajaran yang akan di ajarkannya, sesuai dengan tingkat kemampuannya". ${ }^{13}$

\footnotetext{
${ }^{10}$ Ali Imron, Manajemen Peserta Didik Berbasis Sekolah (Jakarta: Bumi Aksara, 2011), 47.

${ }^{11}$ B. Suryobroto, Manajemen Pendidikan di Sekolah (Jakarta: Rineka Cipta, 2004), 74.

${ }^{12}$ Wawancara dengan Wahib Rifai Ketua Panitia Ujian Masuk, di Kantor MDHY pada tanggal 23 Mei 2013 jam 10.00 s/d 11.00.

${ }^{13}$ Wawancara M. Habibi di Kantor PPHY pada tanggal 12 Maret 2013.
}

Dirasah, Vol. 2, No. 1, Februari 2019 


\section{Orientasi Siswa.}

Orientasi adalah perkenalan. Perkenalan ini meliputi lingkungan fisik sekolah dan lingkungan sosial sekolah. Lingkungan fisik sekolah meliputi prasarana dan sarana sekolah, seperti jalan menuju sekolah, halaman sekolah, tempat bermain di sekolah, lapangan olahraga, gedung dan perlengkapan sekolah serta fasilitas - fasilitas lain yang disediakan di sekolah. Sedangkan lingkungan sosial sekolah meliputi kepala sekolah, guru, tenaga kependidikan selain guru, teman sebaya seangkatan, dan peserta didik senior di sekolah. Lingkungan sosial sekolah tersebut adakalanya tidak terorganisasi. Hal inilah yang kemudian menjadi hal yang penting untuk dikenalkan bagi peserta didik yang baru. ${ }^{14}$

Adapun Kegiatan orientasi siswa di Madrasah Diniyah Haji Ya’qub belum pernah diadakan. Hal ini senada dengan apa yang di katakan oleh bapak kepala madrasah bapak M. Shodiqin:

"Bahwasanya di MDHY tidak ada kegiatan orentasi siswa secara khusus, dan untuk masalah pengenalan siswa terhadap hal-hal yang berkaitan dengan madrasah dicukupkan dengan apa yang di sampaikan oleh bapak-bapak pengajar di kelas masing-masing siswa serta dalam kegiatan Halal bi Halal yang tiap tahunnya diadakan bekerjasama dengan pihak pondok pesantren di mana dalam acara tersebut di isi dengan pembacan tata tertib pondok dan madrasah serta pembacaan susunan kepengurusan pondok dan madrasah." 15

\section{Mengatur kehadiran dan ketidak hadiran siswa}

Kehadiran siswa di sekolah biasa disebut dengan istilah presensi siswa. Pengertian presensi siswa mengandung dua arti, yaitu masalah kehadiran di sekolah (school attendance) dan ketidak hadiran di sekolah (non school attendance). Kehadiran dan ketidak hadiran siswa di sekolah dianggap merupakan masalah penting dalam pengelolaan siswa di sekolah, karena hal ini sangat erat hubungannya dengan prestasi belajar siswa. Di samping itu, kehadiran dan ketidak hadiran siswa di sekolah bisa merupakan gambaran tentang ketertiban suatu sekolah. ${ }^{16}$

\footnotetext{
${ }^{14}$ Minarti, Manajemen Sekolah: Mengelola Lembaga Pendidikan Secara Mandiri (Jogjakarta: Ar-Ruzz Media, 2011), 66.

${ }^{15}$ Wawancara dengan M. Shodiqin selaku mudier I MDHY di kantor MDHY pada tanggal 25 Maret 2013.

${ }^{16}$ FIP IKIP Malang, Administrasi..., 104.
} 
Untuk mengetahui cara Madrasah Diniyah Haji Yaqub dalam menangani absensi siswa, peneliti menemui dan meminta keterangan kepada seksi keamanan, dewan mufatisy, dewan harian serta segenap wali kelas dan petugas pengabsen siswa. Sesuai dengan hasil wawancara peneliti dengan berbagai pihak tersebut kiranya pendapat dari seksi keamanan mewakili dari elemen madrasah yang dalam hal ini disampaikan oleh bapak Khoiruddin, beliau menyatakan bahwa:

"Untuk menangani absensi siswa kiranya perlu dari elemen madrasah ikut berperan memberikan pengertian kepada segenap siswa. Karena keaktifan atau kehadiran siswa di sekolah akan menjadi pertimbangan dalam sidang kenaikan kelas, dimana siswa yang selama satu tahun tidak izin absen selama 30 hari atau lebih maka siswa tersebut tidak bisa naik kelas. ${ }^{17}$

\section{Pengelompokan siswa}

Setelah proses penerimaan siswa baru, maka kegiatan kesiswaan selanjutnya yang perlu dilaksanakan ialah pengelompokan siswa. Pengelompokan siswa diadakan dengan maksud agar pelaksanaan kegiatan proses belajar dan mengajar di sekolah bisa berjalan lancar, tertib dan bisa tercapai tujuan-tujuan pendidikan yang telah di programkan. ${ }^{18}$

Untuk pengelompokan siswa di Madrasah Haji Ya'qub hanya berkisar pengelompokan sesuai dengan kelas masing - masing yang mana pengelompokan tersebut di sesuaikan dengan hasil tes ujian masuk. Bapak M. Shodiqin mengatakan:

"Untuk pengelompokan siswa di MDHY hanya mengikuti hasil ujian test masuk bagi siswa baru serta pengelompokan untuk regu musyawaroh yang dilaksanakan pada sore hari." 19

\section{Evaluasi hasil belajar siswa}

Tujuan dan fungsi evaluasi adalah untuk mengetahui seberapa jauh peserta didik menampilkan performa sebagaimana yang dikehendaki (sudah sesuai atau

\footnotetext{
${ }^{17}$ Wawancara Bapak M. Khoiruddin selaku koordinator sie keamanan MDHY di kantor MDHY pada tanggal 10 April 2013.

${ }^{18}$ Imron, Manajemen Peserta..., 98.

19 Wawancara M. Shodiqin selaku mudier I MDHY di kantor MDHY pada tanggal 25 Maret 2013.
}

Dirasah, Vol. 2, No. 1, Februari 2019 
belum). Pengetahuan mengenai peserta didik demikian, dimaksudkan untuk mengambil keputusan-keputusan penting mengenahi peserta didik apakah perlu di beri pengayaan, nasihat, bimbingan penyuluhan, dipromosikan, dinaikkan kelas, diluluskan dimutasikan dan sebagainya. Dengan kata lain, dengan adanya evaluasi, akan dapat diambil langkah-langkah penting yang berkaitan dengan peserta didik. $^{20}$

Madrasah Diniyah Haji Ya'qub mempunyai 3 metode Evaluasi dalam pembelajaranya. Hal ini sesuai dengan yang dipaparkan oleh bapak M. Shodiqin, yang menjelaskan bahwa di MDHY ada tiga macam evaluasi yang dilakukan oleh para pengajar, yaitu evaluasi harian, evaluasi mingguan dan evaluasi bulanan. Untuk masalah evaluasi harian, sebelum pelajaran dimulai, siswa disuruh untuk musyawaroh dulu membahas pelajaran yang telah diajarkan sebelumnya, dengan dipimpin oleh salah satu siswa yang bertugas sebagai rois $^{21}$ merangkap sebagai moderator guna mengatur jalannya musyawaroh. Sedangkan pengajar hanya mengawasi jalannya musyawaroh. Sedangkan untuk evaluasi mingguan, setiap hari Senin diadakan tamrin (ulangan harian), dan untuk evaluasi bulanan dilakukan setiap enam bulan sekali yaitu ujian semester ganjil dan ujian semester genap. ${ }^{22}$

\section{Pembinaan disiplin siswa}

Masalah disiplin merupakan suatu masalah penting yang dihadapi sekolah dewasa ini. Bahkan sering masalah disiplin digunakan sebagai barometer pengukur kemampuan kepala sekolah dalam memimpin sekolahnya. ${ }^{23}$ Guru dan peserta didik lazimnya membuat semacam kontrak perjanjian yang berisi aturanaturan kedisiplinan yang harus di taati bersama. Sanksi atas pelanggaran disiplin juga akan di taati dan di buat bersama. ${ }^{24}$

Dalam upaya mengatur kedidisiplinan siswa, baik disiplin dalam kehadiran atau disiplin dalam hafalan bapak M. Shodiqin mengatakan: "Usaha yang dilakukan madrasah adalah mengatur jadwal jam aktif sekolah dan jam aktif musyawaroh, di samping itu juga menghimbau kepada para pengajar untuk selalu

\footnotetext{
${ }^{20}$ Imron, Manajemen Peserta..., 120.

${ }^{21}$ Rois adalah seorang yang memimpin jalannya musyawarah sekaligus pembaca materi pelajaran yang di gunakan untuk musyawarah.

${ }^{22}$ Wawancara dengan M. Shodiqin selaku mudier I MDHY di kantor MDHY pada tanggal 25 Maret 2013.

${ }^{23}$ Imron, Manajemen Peserta Didik..., 108.

${ }^{24}$ Ibid,. 175.
} 
hadir tepat waktu dan menunggu siswanya yang sedang musyawaroh". ${ }^{25}$ Bapak Imam Waliyyudin selaku Mudier dua mengatakan:

'Guna untuk mendisiplinkan siswa dalam belajar, musyawaroh dan hafalan adalah dengan menunggu siswa yang sedang musyawaroh dan juga memberi takziran atau hukuman kepada siswa yang hadirnya terlambat dan juga memanggil siswa yang tidak aktif sekolah atau musyawaroh dan tidak hafal pelajaran. ${ }^{26}$

\section{Kenaikan Kelas}

Sebelum kita membuat keputusan tentang naik kelas atau tidak naik kelas terhadap seorang siswa (dalam rapat pleno kenaikan kelas), biasanya para wali kelas diminta untuk membuat atau menentukan perkiraan bagaimana kemungkinan-kemungkinan yang akan terjadi terhadap siswa-siswa dalam kelasnya. Perkiraan tentang kemungkinan-kemungkinan ini bisa kita sebut sebagai prakeputusan. Prakeputusan-prakeputusan ini akan merupakan bahan pembahasan dalam rapat pleno untuk mengambil keputusan-keputusan. ${ }^{27}$

Prosedur yang digunakan oleh Madrasah Diniyah Haji Ya'qub dalam menaikkan siswanya adalah siswa dinyatakan naik kelas apabila aktif dalam mengikuti kegiatan belajar di sekolah. Di samping itu juga mereka harus mengikuti ujian kenaikan kelas. Dan dinyatakan tidak naik kelas atau tinggal kelas, apabila mereka dalam satu tahun tidak aktif sebanyak 30 hari bahkan lebih. Hal ini sesuai dengan apa yang di ungkapkan oleh bapak M. Shodiqin selaku Mudier madrasah yaitu:

"Bahwasanya siswa akan dinaikkan kelas, apabila mereka aktif dalam mengikuti kegiatan belajar dan mengikuti ujian kenaikan." 28

\section{Mengatur siswa yang mutasi atau drop out.}

Mutasi adalah perpindahan peserta didik dari kelas yang satu ke kelas yang lain yang sejajar, dan atau perpindahan peserta didik dari sekolah lain yang

\footnotetext{
${ }^{25}$ Wawancara Bapak M. Shodiqin selaku mudier I MDHY di kantor MDHY pada tanggal 25 Maret 2013.

${ }^{26}$ Wawancara dengan Imam Waliyyudin selaku mudier II MDHY di kantor MDHY pada tanggal 15 maret 2013.

${ }^{27}$ FIP IKIP Malang, Administrasi..., 111.

${ }^{28}$ Wawancara dengan M. Shodiqin selaku mudier I MDHY di kantor MDHY pada tanggal 25 Maret 2013.
}

Dirasah, Vol. 2, No. 1, Februari 2019 
sejajar. Mutasi ini dapat dilakukan oleh peserta didik, karena mereka berhak untuk mendapatkan layanan pendidikan sesuai dengan yang di butuhkan dan diminati. Meskipun untuk melakukan mutasi mereka harus memenuhi persaratan-persaratan tertentu yang ditentukan oleh sekolah yang menerimanya. ${ }^{29}$ Dengan harapan nantinya pihak sekolah akan mengetahui profil atau latar belakang dari siswa tersebut. Sedangkan yang dimaksud dengan droup out adalah keluar dari sekolah sebelum waktunya, atau sebelum lulus. Droup out ini perlu dicegah karena menyebabkan pemborosan biaya. ${ }^{30}$ Penanganan droup out tentu tidak bisa dilaksaanakan oleh pihak sekolah sendiri, melainkan haruslah terpadu dan bersama-sama dengan lingkungan lain yaitu keluarga dan masyarakat. ${ }^{31}$

Adapun proses mutasi di Madrasah Diniyah Haji Ya'qub hanya berkisar perpindahan dari satu kelas ke kelas yang lain dalam satu tingkatan setiap satu tahun sekali. Hal ini ditempuh agar siswa bisa berbaur dengan siswa di kelas lain.

\section{Kelulusan Siswa}

Kelulusan adalah pernyataan dari sekolah sebagai suatu lembaga tentang telah diselesaikannya program pendidikan yang harus diikuti oleh siswa. Setelah seorang siswa selesai mengikuti seluruh program pendidikan di suatu sekolah dan berhasil lulus dalam EBTA, maka kepadanya di berikan surat keterangan atau sertifikat, yang umumnya disebut ijazah atau surat tanda tamat belajar (STTB). ${ }^{32}$ Proses kelulusan biasanya ditandai atau di kukuhkan dalam suatu upacara, yang bisa juga disebut dengan "Upacara Kelulusan" atau "Pelepasan Siswa".

Prosesi kelulusan siswa di Madrasah diniyah haji ya'qub tidak jauh beda dengan madrasah atau sekolah formal yang lain. Agenda ini biasanya di langsungkan bersamaan dengan acara haflah akirossanah pondok dan madrasah. Siswa tamatan dari semua tingkatan mulai I'dadiyah, Ibtidaiyyah, tsanawiyah dan aliyah mendapatkan kehorhatan untuk naik ke panggung kehormatan sebagai wisudawan dan berhak mendapatkan ijazah sesuai dengan tingkatnya masingmasing.

\footnotetext{
${ }^{29}$ Imron, Manajemen Peserta..., 152.

${ }^{30}$ Ibid,. 153.

31 Ibid., 159.

${ }^{32}$ FIP IKIP Malang, Administrasi..., 120.
} 


\section{Pembahasan}

Berdasarkan hasil wawancara, observasi dan dokumentasi yang peneliti dapatkan dari segenap komponen Madrasah Diniyyah Haji Ya'qub (MDHY), bahwasanya penerapan manajemen kesiswaan di madrasah ini sudah cukup baik, hal ini bisa di lihat dari perencanaan yang telah di buat oleh pihak madrasah, yang mana perencanaan ini telah terbukukan dalam sebuah buku yang diberi nama Hasil Sidang Istimewa (HSI). Dan kegunaan buku tersebut adalah sebagai pedoman bagi para pengurus dan pengajar, dalam menjalankan aktifitas mengajarnya selama setahun. Hal ini sesuai dengan pendapat Ali Imron yang mengatakan dalam bukunya Manajemen Peserta Didik Berbasis Sekolah yang menyatakan bahwa "Perencanaan peserta didik adalah suatu aktivitas memikirkan di muka tentang hal-hal yang harus dilakukan berkenaan dengan peserta didik di sekolah, baik sejak peserta didik akan memasuki sekolah maupun mereka akan lulus sekolah". ${ }^{33}$

Sedangkan untuk penerimaan siswa baru, MDHY menggunakan sistem seleksi dengan mengharuskan setiap siswa baru untuk mengikuti ujian tes masuk kecuali kelas 1 ibtida'iyah. Untuk menangani penerimaan siswa baru ini pun MDHY telah menunjuk dan menetapkan panitia ujian masuk yang diberi nama PANJIMAS yang bertugas untuk menangani segala keperluan yang di butuhkan dalam penerimaan siswa baru yang diantaranya adalah melayani pendaftaran tes, menentukan penguji dan pengawas ujian tes, mengevaluasi hasil ujian seleksi, menentukan kelulusan ujian serta mengumumkan hasil ujian seleksi.

Siswa yang telah mendaftarkan diri, selanjutnya akan di uji atau di tes seleksi melalui ujian lesan dan ujian tulis dengan materi yang sesuai dengan tingkatan kelas yang akan di masukinya. Untuk tingkat kelas satu ibtidaiyyah bisa langsung masuk tanpa melalui ujian masuk, dan untuk kelas dua sampai kelas empat ibtida'iyyah dengan materi fasholatan dan hafalan surat-surat pendek, sedangkan untuk kelas satu tsanawiyah ujiannya berupa setor hafalan nadhom alfiyyah minimal 150 bait, baca kitab fathul qorib tanpa ma'na dan juga tes tulis. Sedangkan untuk kelas satu aliyah ujian seleksinya berupa setor hafalan nadhom jauharul maknun minimal 150 bait, baca kitab fathul mu'in dan ujian tulis. Dengan seleksi ini, di harapkan supaya siswa benar - benar sudah siap mengikuti pelajaran di kelas yang akan di masukinya. Setelah siswa benar-benar dinyatakan lolos seleksi ujian masuk, maka oleh panitia siswa tadi akan di kelompokkan

${ }^{33}$ Imron, Manajemen Peserta..., 21.

Dirasah, Vol. 2, No. 1, Februari 2019 
sesuai dengan kelas masing-masing sesuai dengan tingkatannya. Hal ini akan lebih memudahkan bagi para pengajar dalam memberikan materi pelajaran, karena materi pelajaraanya telah di sesuakan untuk kelas masing-masing. Hal tersebut senada dengan pendapat Ali imron yang mengatakan bahwa "Pengelompokan siswa diadakan dengan maksud agar pelaksanaan kegiatan proses belajar dan mengajar di sekolah bisa berjalan lancar, tertib dan bisa tercapai tujuan-tujuan pendidikan yang telah di programkan". ${ }^{34}$

Selanjutnya untuk orentasi siswa baru, di MDHY belum melaksanakannya, kegunaan orentasi ini adalah untuk mengenalkan terhadap siswa-siswa baru pada lingkungan barunya, baik itu teman seniornya atau dewan pengajar yang akan membimbinnya. Di lembaga ini tidak di laksanakannya orentasi karena pihak madrasah merasa sudah cukup dengan apa yang telah di sampaikan para dewan guru terhadap siswanya serta acara halal bi halal di awal tahun ajaran yang diselenggaraakan bersama dengan acara pondok pesantren dengan di isi pembacaan tata tertib dan kepengurusan pondok dan madrasah. Jika merujuk pada buku Administrasi Pendidikan yang dikarang oleh Team Dosen administrasi pendidikan FIP IKIP Malang, dengan melihat berbagai kegiatan yang bisa di gunakan untuk mengisi masa orientasi siswa, kiranya bisa untuk di terapkan di Madrasah Diniyah Haji Ya'qub. Kegiatan-kegiatan itu biasanya diisi dengan:

1) Perkenalan dengan para guru dan staf sekolah.

2) Perkenalan dengan siswa lama.

3) Perkenalan dengan pengurus osis.

4) Penjelasan tentang tata tertib sekolah.

5) Mengenal dan meninjau fasilitas-fasilitas sekolah, misalnya laboratorium, perpustakaan, sanggar musik dan lain sebagainya. ${ }^{35}$

Di tambah lagi, hal tersebut akan bisa lebih bagus jika para siswa baru ini mendapatkan pengarahan atau bimbingan tersendiri untuk lebih mengenal kondisi lingkungan serta untuk lebih mengenal adat istiadat yang terlaku di madrasah pada khususnya serta di pesantren pada umumnya.

Untuk mendisiplinkan siswa dalam memaksimalkan tingkat kehadirannya, MDHY sudah bagus, karena disamping setiap harinya bapak pengajar mengontrol absensi siswa, setiap bulannya pun para pengabsen siswa juga diharuskan melaporkan hasil absensinya kepada dewan mufatisy, yang selanjutnya akan di laporkan ke pihak keamanan madrasah. Bagi para siswa yang

\footnotetext{
34 Ibid., 98.

${ }^{35}$ FIP IKIP Malang, Administrasi..., 98.
} 
dalam absensinya terdapat $\mathrm{T}$ (tidak hadir tanpa keterangan) lebih dari 4 kali setiap bulannya, maka siswa tadi akan di panggil lalu di introgasi mengenahi absensinya. Bagi siswa yang benar-benar melanggar maka akan di beri ta'ziran atau hukuman. Oleh karena itu, siswa akan lebih mudah terkontrol dalam masalah keaktifan sekolah dan musyawarohnya. Sebagaimana pendapat ali imron yang mengatakan bahwa kontrak antara guru dengan peserta didik mengenahi sanksi atas mereka yang terlambat juga dapat di buat, agar mereka sama - sama menepati waktu yang telah dijadwalkan. ${ }^{36}$

Disamping menangani absensi siswa, Madrasah Diniyah Haji Ya'qub juga mengatur tentang kewajiban apa saja yang harus dilakukan oleh pengajar dalam menjalankan tugasnya. Hal ini supaya ada keseimbangan antara kedua belah pihak yaitu siswa dan pengajar. Sehingga untuk mewujudkan kedisiplinan itu akan lebih mudah tercapai. Diantara upaya tersebut adalah dengan mengharuskan setiap pengajar untuk membubuhkan tanda tangan setiap kali mengajar. Hal ini ditempuh agar pihak madrasah juga mengetahui keaktifan pengajar.

Selain itu, guna mengetahui kedisiplinan siswa dalam belajar serta untuk mengetahui kefahaman siswa terhadap materi pelajaran yang disampaikan oleh guru, maka di Madrasah Diniyah Haji Ya'qub, telah mengadakan evaluasi yang terdiri dari avaluasi harian, evaluasi mingguan dan evaluasi bulanan. Untuk evaluasi bulanan dalam setahun di lakukan dua kali ujian yaitu ujian semester ganjil dan ujian semester genap. Sedangkan untuk bisa mengikuti ujian semester ganjil dan genap ini, siswa harus lolos koreksian kitab dan lolos ujian mukhafadhoh. Selain itu pada tiap - tiap pelajaran yang mengharuskan siswa hafalan maka tiap kali pertemuan siswa juga diharuskan untuk menghafalakan pelajaran tersebut. Hal ini di tempuh agar siswa mau untuk belajar mengulangi pelajaran yang telah di sampaikan.

Setelah siswa mengikuti evaluasi belajar berupa ujian semester genap pada akhir tahun, maka dari hasil nilai ujian ini dan keaktifan siswa dalam belajar selama setahun, digunakan untuk mengisi buku raport. Yang mana dalam buku raport tersebut memuat tentang nilai dan kenaikan kelas siswa. Kenaikan kelas tadi, ditandai dengan pembagian buku raport oleh wali kelas masing-masing siswa. Sedangkan untuk kelulusan siswa ditandai dengan di keluarkannya syarat tanda tamat belajar atau ijazah. Di Madrasah Diniyah Haji Ya'qub, ijazah ini diberikan pada waktu acara haul dan haflah akhirussanah akhir tahun.

${ }^{36}$ Imron, Manajemen Peserta..., 89.

Dirasah, Vol. 2, No. 1, Februari 2019 
Jika melihat latar belakang siswa Madrasah Diniyah Haji Ya'qub adalah siswa-siswa yang mondok sambil sekolah di pendidikan formal dan bahkan juga bekerja, maka hal ini menjadi problem tersendiri bagi pihak madrasah. Problem itu diantaranya adalah problem kondisi fisik siswa yang sudah terkuras dikarenakan telah sejak pagi hari mengikuti aktifitas di sekolah umum, sehingga ketika malam harinya, siswa dalam mengikuti belajar di madrasah kurang bisa optimal. Dan faktor minimnya waktu yang mereka gunakan untuk memperdalam pelajaran diniyah. Disamping itu, ada beberapa siswa yang masih rendah dalam semangatnya untuk belajar, hal ini sedikit banyak mempengaruhi kedisiplinan, baik disiplin dalam mengikuti pelajaran atau keaktifan mereka dalam bermusyawaroh serta ketertiban dan keamanan.

Selain problem yang muncul dari siswa, problem lain yang dihadapi pihak madrasah dalam melaksanakan manajemen kesiswaan diantaranya adalah problem yang muncul dari komponen madrasah yaitu ada sebagian dari guru atau asatidz yang kurang begitu aktif untuk memberikan pelajaran serta kurang mengetahui kondisi fisik dan psikis para siswa. Serta yang tidak kalah pentingnya adalah perlunya bimbingan kepada para siswa baru seperti program orientasi siswa baru untuk lebih mengenalkan siswa kepada lingkungan fisik dan lingkungan sosialnya di madrasah.

Upaya yang di lakukan oleh madrasah adalah dengan memberi motivasi dan semangat kepada siswanya agar mereka tetap terpacu dalam belajarnya meskipun kondisi yang sudah lemah. Dan juga melakukan pemanggilan terhadap siswa tidak aktif sekolah atau musyawaroh guna untuk di arahkan dan di beri takziran atau hukuman. Hal ini sebagai pembelajaran kepada siswa agar mereka selalu hidup disiplin dan bisa memanfaatkan waktunya yang semaksimal mungkin. selain itu, pihak madrasah juga mengadakan tambahan jam belajar dan selalu menghimbau segenap siswa untuk mengikuti pengajian kitab sorogan kitab dan forum-forum musyawarah. Hal ini supaya siswa bisa mendapatkan pemahaman lebih pada pelajaran di sekolahnya.

Di samping itu, pihak madrasah lebih sering lagi untuk mengintruksikan kepada segenap guru terutama wali kelas agar selalu memperhatikan siswasiswanya untuk aktif dalam semua kegiatan madrasah, dengan cara misalnya mendampingi siswanya saat musyawarah, memberikan peringatan bagi yang melanggar dan lain sebagainya. Dan yang perlu di rencanakan adalah mengadakan bimbingan bagi santri baru seperti halnya masa orientasi siswa (MOS) guna memperkenelkan siswa terhadap lingkungan barunya. 


\section{Penutup}

Dari hasil penelitian penulis di Madrasah Diniyyah Haji Ya'qub (MDHY) Lirboyo Kota Kediri mengenai penerapan manajemen kesiswaan di madrasah tersebut, maka dapat diambil kesimpulan sebagai berikut:

1. Madrasah Diniyyah Haji Ya'qub Lirboyo Kota Kediri telah mampu melaksanakan beberapa hal yang menjadi bagian dari manajemen kesiswaan sesuai dengan ketentuan yang ada.

2. Problematika yang dihadapi Madrasah Diniyyah Haji Ya'qub Lirboyo Kota Kediri dalam melaksanakan manajemen kesiswaan adalah:

a. Masih banyaknya siswa yang belum mampu mengenal lingkungan fisik dan lingkungan sosial di lokasi madrasah. Lingkungan fisik sekolah meliputi prasarana dan sarana sekolah, seperti jalan menuju sekolah, halaman sekolah, tempat bermain di sekolah, lapangan olahraga, gedung dan perlengkapan sekolah serta fasilitas - fasilitas lain yang disediakan di sekolah. Sedangkan lingkungan sosial sekolah meliputi kepala sekolah, guru, tenaga kependidikan selain guru, teman sebaya seangkatan, dan peserta didik senior di sekolah.

b. Kondisi siswa yang letih ketika mengikuti belajar di madrasah serta Kurangnya himmah atau semangat dan kesungguhan siswa dalam memahami pelajaran agama sehingga mengakibatkan kurang aktifnya siswa dalam mengikuti kegiatan belajar.

c. Tingkat kehadiran siswa masih kurang maksimal.

3. Tindakan yang ditempuh Madrasah Diniyyah Haji Ya'qub Lirboyo Kota Kediri dalam mengatasi problematika tersebut adalah sebagai berikut:

a. Menghimbau kepada segenap pengajar untuk menginstruksikan siswanya guna mengikuti acara-acara yang di prakarsai oleh pondok dan madrasah dalam kaitannya untuk lebih mengenal lingkungan fisik maupun sosial para siswa

b. Mengintruksikan kepada segenap guru terutama wali kelas agar selalu memperhatikan siswa-siswanya untuk aktif dalam semua kegiatan madrasah. Dan sesering mungkin memberikan motivasi kepada para siswa agar mereka mempunyai semangat dalam belajarnya.

c. Melakukan pemanggilan terhadap siswa yang tidak aktif sekolah atau musyawaroh guna untuk di arahkan dan di beri takziran atau hukuman. 


\section{Daftar Pustaka}

Anwar, Ali. Pembaruan Pendidikan di Pesantren Lirboyo Kediri, Yogyakarta: Pustaka Pelajar, 2011.

Danim, Sudarwan Menjadi Peneliti Kualitatif, Bandung: CV Pustaka Setia, 2002.

Imron, Ali. Manajemen Peserta Didik Berbasis sekolah, Jakarta : Bumi Aksara, 2011.

Marzuki, Metodelogi Riset, Yogyakarta: BPFE-UII, 2000.

Minarti, Sri. Manajemen Sekolah:Mengelola Lembaga Pendidikan Secara Mandiri, Jogjakarta: Ar-Ruzz Media, 2011.

Qomar, Mujamil Manajemen Pendidikan Islam: Strategi Baru Pengelolaan lembaga Pendidikan Islam, Jakarta: Erlangga, 2007.

Saefullah, U. Manajemen Pendidikan Islam, Bandung: Pustaka Setia, 2012.

Sugiyono, Memahami Penelitian Kualitatif, Bandung : Alfabeta, 2005.

Sumadi, Metodologi Penelitian, Jakarta: Raja Grafindo Persada, 1998.

Suryobroto, B..Manajemen Pendidikan Di Sekolah, Jakarta:Rineka Cipta, 2004.

Tim Dosen Jurusan Administrasi Pendidikan FIP IKIP Malang, Administrasi Pendidikan, Malang: Penerbit IKIP Malang, 1989.

Copyright @ 2019 Journal Dirasah: Vol. 2, No. 1, Februari 2019, p-ISSN: 2615-0212, e-ISSN; 2621-2838

Copyright rests with the authors

Copyright of Jurnal Dirasah is the property of Jurnal Dirasah and its content may not be copied or emailed to multiple sites or posted to a listserv without the copyright holder's express written permission. However, users may print, download, or email articles for individual use.

https://ejournal.iaifa.ac.id/index.php/dirasah 